\title{
ANALISIS FAKTOR-FAKTOR YANG MEMPENGARUHI KEPUTUSAN KONSUMEN DALAM PEMBELIAN PRODUK MAKANAN DAN MINUMAN HALAL DI JAKARTA
}

\author{
Muhammad Tony Nawawi ${ }^{1}$ \\ ${ }^{1}$ Fakultas Ekonomi, Universitas Tarumanagara Jakarta. \\ Email: tonyn@fe.untar.ac.id
}

\begin{abstract}
ABSTRAK
Penelitian ini bertujuan untuk mengetahui pengaruh variabel sikap, norma subyektif, persepsi kontrol perilaku, dan niat keputusan membeli produk yang aman dan halal bagi umat Islam di Universitas Tarumanagara. Analisis menggunakan analisis dua jalur menggunakan program SPSS. Analisis dibagi menjadi dua: pertama keputusan untuk membeli produk aman dan keputusan untuk membeli produk halal. Hasil penelitian ini diharapkan dapat bermanfaat bagi konsumen untuk lebih memperhatikan keamanan dan produk halal yang harus dibeli. Pemerintah diharapkan secara tegas mewajibkan pengusaha untuk memberikan keamanan informasi dan produk halal, karena legalitas dan sertifikasi produk halal akan memberikan perlindungan dan kemudahan pembelian produk-produk. Bagi pengusaha muslim di hadapan jaminan keamanan dan produk halal, diharapkan akan meningkatkan daya saing dan penjualan.
\end{abstract}

Kata kunci: makanan dan minuman, keamanan dan halal, konsumen Muslim, keputusan pembelian produk.

\section{PENDAHULUAN}

Negara Indonesia merupakan Negara yang memiliki penduduk mayoritas beragama islam terbesar di dunia, menurut sensus penduduk tahun 2010 85,1 \% dari 240.271 .522 penduduk Indonesia adalah pemeluk agama islam (Sensus Penduduk Indonesia, 2010). Indonesia merupakan negara yang memiliki jumlah Umat Islam yang terbesar di dunia. Umat Islam yang besar menjadi pasar yang potensial untuk menjual produk yang memenuhi syarat-syarat yang diperlukan konsumen muslim.

Hal ini, akan mempengaruhi pemerintah untuk terus meningkatkan perhatiannya terhadap produk makanan dan minuman yang beredar di masyarakat. Pemerintah, dalam hal ini diwakili oleh Kementrian Agama dan dibantu oleh Majelis Ulama Indonesia (MUI) berusaha untuk menyaring produk makanan dan minuman yang beredar di Indonesia harus mengikuti hukum syariah agama islam. Hal ini, dapat direalisasikan dengan pemberian sertifikat halal (label halal) pada makanan dan minuman tersebut. Menurut Suryani (2008:6), Perilaku Konsumen merupakan studi tentang bagaimana individu, kelompok dan organisasi dan proses yang dilakukan untuk memilih, mengamankan, menggunakan dan menghentikan penggunaan produk atau jasa, pengalaman atau pemikiran untuk memuaskan kebutuhannya dan dampak terhadap konsumen dan masyarakat.

Dewasa ini konsumen sudah memiliki kepedulian yang tinggi dan semakin kritis dalam mencari serta menggali informasi tentang produk yang akan digunakan. Informasi tentang produk dapat diperoleh melalui beberapa sumber, antara lain sumber personal (keluarga, tetangga, kenalan), sumber komersial ( promosi), sumber publik (media massa), dan sumber percobaan (meneliti, menggunakan produk). Dalam sebuah produk terdapat informasi mengenai bentuk fisik produk, label dan sisipan (instruksi detail dan informasi keamanan untuk produk) yang dapat digunakan konsumen untuk memperoleh informasi yang lebih mendalam mengenai suatu produk tertentu 
diinginkannya. Label merupakan bagian dari kemasan dan mengandung suatu informasi tentang produk yang tercetak pada kemasan. Dalam label konsumen dapat menemukan informasi mengenai nama produk, daftar bahan yang digunakan, berat bersih atau isi bersih, nama dan alamat pihak yang memproduksi atau memasukkan ke dalam wilayah yang bersangkutan; tanggal, bulan, dan tahun kadaluwarsa, klaim nutrisi terutama untuk produk kesehatan, petunjuk penggunaan, dan keterangan lain untuk kondisi spesial dan cara penggunaan, serta keterangan tentang halal. Menurut Wakil Direktur LPPOM MUI, Anna P Roswiem, ada tiga formulir yang harus diisi jika suatu produk ingin mendapatkan sertifikasi dan lebelisasi halal dari LPPOM MUI pertama, memenuhi sertifikat halal kedua, mencantum nama produk serta melengkapi dukumen dan ketiga, adanya jaminan produk yang akan disertifikasi."Karena itu, kita mengenal dengan sistem jaminan halal," tutur Anna. Untuk masa berlaku sertifikatnya sendiri, yaitu selama dua tahun.Anna menyayangkan, kendala LPPOM MUI dalam menerbitkan sertifikat halal seperti pengetahuan pengusaha atau produsen tentang halal, kurangnya akses informasi dari perusahaan ke MUI atau LPPOM MUI juga sebaliknya, dan belum ada peraturan yang jelas tentang sertifikasi halal dari pemerintah. . Sikap adalah evaluasi, perasaan emosi, dan kecenderungan tindakan yang menguntungkan atau tidak menguntungkan dan bertahan lama pada seseorang terhadap suatu objek atau gagasan tertentu.(David Kreh, dalam Kotler 2003:219).

Salah satu produk yang perlu diperhatikan keamanan dan kehalalan adalah makanan dan minuman. Masyarakat telah meningkat kesadarannya tentang keamanan makanan dan minuman yang dikonsumsinya, karena banyaknya kasus yang menunjukkan resiko akibat mengkonsumsi makanan dan minuman. Sebagai umat Islam yang memiliki aturan yang sangat jelas tentang halal dan haram suatu produk, seharusnya muslim konsumen terlindungi dari produk-produk makanan yang tidak halal atau tidak jelas kehalalannya (syubhat).Namun pengetahuan saja tidak cukup karena sampai saat ini masih sedikit produsen makanan dan minuman yang mencantumkan komposisi bahan produknya pada label kemasan. Pemahaman agama dapat mempengaruhi perilaku konsumen dalam pemilihan produk makanan dan minuman yang akan dibeli. Penelitian ini dilakukan untuk mengetahui pengaruh sikap, norma subyektif, dan persepsi kontrol perilaku muslim terhadap niatnya dalam mengambil keputusan pembelian produk makanan dan minuman. Penelitian ini dilakukan agar dapat membantu konsumen muslim dalam mengambil keputusan pembelian produk makanan dan minuman dapat lebih memperhatikan keamanan dan kehalalan produk yang dipilih. Penelitian ini akan mengambil sampel muslim konsumen di Untar Jakarta sebagai obyek penelitian. Permasalahan dalam penelitian ini adalah:

1). Apakah ada pengaruh sikap, norma subyektif dan persepsi kontrol perilaku terhadap niat memilih produk makanan yang aman pada muslim konsumen ?

2). Apakah ada pengaruh sikap, norma subyektif, persepsi kontrol perilaku terhadap keputusan pembelian produk mimunan yang aman melalui variabel niat pada muslim konsumen?

3). Apakah ada pengaruh sikap, norma subyektif dan persepsi kontrol perilaku terhadap niat memilih produk makanan yang halal pada muslim konsumen ?

4). Apakah ada pengaruh sikap, norma subyektif, persepsi kontrol perilaku terhadap keputusan pembelian produk minuman yang halal melalui variabel niat pada muslim konsumen ? 


\section{METODE PENELITIAN}

\section{Populasi dan Metode Pengambilan Sampel}

Populasi penelitian ini adalah Seluruh konsumen muslim yang ada di Universitas Tarumanagara Jakarta. Namun karena keterbatasan yang ada pada peneliti, maka populasi tersebut akan diambil sebagian saja dari keseluruhannya, yaitu dengan teknik pengambilan sampel tidak acak yang berupa convenience random sampling, dimana Convenience sampling dilakukan dengan memilih sampel yang paling mudah untuk dimintai menjadi responden. Peneliti mengambil responden dari sivitas akademika muslim (mahasiswa, karyawan, dan dosen) sebanyak 120 responden yang ada di Universitas Tarumanagara Jakarta. Menurut Malhotra (2005) bahwa populasi yang ditentukan untuk menjadi sampel didasarkan pada tujuan penelitian, sehingga banyaknya jumlah sampel (responden) yang diambil untuk penelitian minimal 4 atau 5 kali jumlah atribut pernyataan yang digunakan dalam penelitian. Oleh karena itu, dalam penelitian ini atribut yang dipergunakan sebanyak 32 atribut pernyataan. Sehingga untuk penelitian jumlah sampelnya diambil sebanyak 120 sampel responden.

Penelitian ini menggunakan desain pengambilan sampel secara non probabilistic, artinya probabilitas dari elemen populasi yang dipilih tidak diketahui (Cooper dan Schindler, 2006: 407).

\section{HASIL DAN PEMBAHASAN}

Berdasarkan perhitungan diperoleh angka korelasi antara variabel sikap dengan norma subyektif sebesar 0,067, menunjukkan hubungan antara variabel sikap dengan norma subyektif sangat lemah. Angka signifikansinya hasil perhitungan sebesar 0,234>0,05, maka korelasi kedua variabel tersebut tidak signifikan. Angka korelasi antara sikap dan persepsi kontrol perilaku sebesar 0,449, menunjukkan hubungan positip dan cukup kuat. Angka signifikansi hasil perhitungan sebesar $0,00<0,05$, maka korelasi kedua variabel tersebut signifikan. Korelasi antara norma subyektif dan persepsi kontrol perilaku sebesar 0,237 mendekati cukup kuat. Angka signifikansi hasil perhitungan $0,005<0,05$ menunjukkan korelasi kedua variabel signifikan.

Pengaruh secara gabungan dari variabel sikap, norma subyektif, dan persepsi kontrol perilaku terhadap niat membeli makanan dan minuman yang aman sebesar 0,253. Angka tersebut mempunyai arti pengaruh sikap, norma subyektif, dan persepsi kontrol perilaku terhadap niat membeli makanan dan minuman yang aman sebesar secara gabungan adalah 25,3 \%, sedangkan sisanya sebesar 74,7 \% dipengaruhi oleh variabel-variabel lain di luar model.

Pengaruh secara parsial sikap terhadap niat adalah sebesar 0,245. Hasil perhitungan menunjukkan taraf siginfikansi $0,8 \%<$ taraf signifikansi penelitian $5 \%$, maka pengaruh sikap terhadap niat membeli makanan dan minuman yang aman signifikan.

Pengaruh secara parsial norma subyektif terhadap niat membeli makanan dan minuman yang aman sebesar 0,136. Hasil tersebut tidak signifikan karena taraf signifikansi perhitungan 10,2\% sedangkan taraf signifikansi tabel sebesar 5\%, yang berarti pengaruh norma subyektif terhadap niat membeli produk makanan dan minuman yang aman rendah.

Sedangkan pengaruh secara parsial persepsi kontrol perilaku terhadap niat membeli makanan dan minuman yang aman sebesar 0,294. Hasil tersebut signifikan karena taraf signifikansi perhitungan $0,2 \%$ sedangkan taraf signifikansi tabel sebesar $5 \%$. 
Berdasarkan perhitungan diperoleh angka korelasi antara variabel sikap dengan norma subyektif sebesar -0,039, menunjukkan hubungan antara variabel sikap dengan norma subyektif sangat lemah. Angka signifikansinya hasil perhitungan sebesar $0,671>0,05$, maka korelasi kedua variabel tersebut tidak signifikan. Angka korelasi antara sikap dan persepsi kontrol perilaku sebesar 0,154, menunjukkan hubungan positip dan cukup kuat. Angka signifikansi hasil perhitungan sebesar ,093>0,05, maka korelasi kedua variabel tersebut tidak signifikan. Korelasi antara norma subyektif dan persepsi kontrol perilaku sebesar -,078 mendekati cukup kuat. Angka signifikansi hasil perhitungan 0,005 < 0,05 menunjukkan korelasi kedua variabel signifikan.

Pengaruh secara gabungan dari variabel sikap, norma subyektif, dan persepsi kontrol perilaku terhadap niat membeli makanan dan minuman yang aman dan halal sebesar 0,308. Angka tersebut mempunyai arti pengaruh sikap, norma subyektif, dan persepsi kontrol perilaku terhadap niat membeli makanan dan minuman yang aman dan halal sebesar secara gabungan adalah 30.80 $\%$, sedangkan sisanya sebesar 69,20\% dipengaruhi oleh variabel-variabel lain di luar model.

Pengaruh variabel sikap, norma subyektif, dan persepsi kontrol perilaku dengan niat membeli makanan dan minuman yang aman dan halal terjadi apabila angka signifikansi perhitungan lebih kecil dari angka signifikansi penelitian yaitu $5 \%$. Hasil perhitungan menunjukkan taraf signifikansi sebesar 0,00 lebih kecil dari angka signifikansi penelitian ini 0,05 yang berarti terdapat pengaruh yang signifikasi.

Besarnya pengaruh secara parsial dari sikap, norma subyektif, dan persepsi kontrol perilaku terhadap niat membeli makanan dan minuman yang aman digunakan angka beta atau standardized coeffecient dan pengujian dilakukan dengan uj-t.

Sedangkan diperoleh angka korelasi antara variabel sikap dengan norma subyektif sebesar 0,067, menunjukkan hubungan antara variabel sikap dengan norma subyektif sangat lemah. Angka signifikansinya hasil perhitungan sebesar 0,234>0,05, maka korelasi kedua variabel tersebut tidak signifikan. Angka korelasi antara sikap dan persepsi kontrol perilaku sebesar 0,449, menunjukkan hubungan positip dan cukup kuat. Angka signifikansi hasil perhitungan sebesar $0,00<0,05$, maka korelasi kedua variabel tersebut signifikan. Korelasi antara norma subyektif dan persepsi kontrol perilaku sebesar 0,237 mendekati cukup kuat. Angka signifikansi hasil perhitungan 0,005 $<0,05$ menunjukkan korelasi kedua variabel signifikan. Korelasi antara sikap dengan niat sebesar 0,386 menunjukkan korelasi yang cukup kuat. Angka signifikansi hasil perhitungan $0,00<0,05$ menunjukkan korelasi kedua variabel signifikan. Korelasi antara norma subyektif dan niat sebesar 0,222 mendekati cukup kuat. Angka signifikansi hasil perhitungan $0,007<0,05$ menunjukkan korelasi kedua variabel signifikan. Korelasi antara persepsi kontrol perilaku dengan niat sebesar 0,436 menunjukkan hubungan yang cukup kuat. Angka signifikansi hasil perhitungan $0,000<0,05$ menunjukkan korelasi kedua variabel signifikan.

Pengaruh secara gabungan dari variabel sikap, norma subyektif, dan persepsi kontrol perilaku terhadap niat membeli makanan dan minuman yang aman sebesar 0,349. Angka tersebut mempunyai arti pengaruh sikap, norma subyektif, dan persepsi kontrol perilaku terhadap niat membeli makanan dan minumanyang aman sebesar secara gabungan adalah 34,9\%, sedangkan sisanya sebesar 65,1\% dipengaruhi oleh variabel-variabel lain di luar model.

Pengaruh variabel sikap, norma subyektif, persepsi kontrol perilaku, dan niat dengan keputusan membeli makanan dan minuman yang aman terjadi apabila angka signifikansi perhitungan lebih 
kecil dari angka signifikansi penelitian yaitu 0,05 (5\%). Hasil perhitungan menunjukkan taraf signifikansi sebesar 0,00 lebih kecil dari angka signifikansi penelitian ini 0,05 yang berarti terdapat pengaruh yang signifikan.

Besarnya pengaruh secara parsial dari sikap, norma subyektif, dan persepsi kontrol perilaku, niat terhadap keputusan membeli makanan dan minuman yang aman dan halal digunakan angka beta atau standardized coeffecient dan pengujian dilakukan dengan uj-t. Pengaruh secara parsial sikap terhadap keputusan membeli produk makanan dan minuman yang aman adalah sebesar 0,240. Hasil perhitungan menunjukkan taraf siginfikansi $0,7 \%<$ taraf signifikansi penelitian 5\%, maka terdapat pengaruh sikap terhadap keputusan membeli makanan dan minuman yang aman dan halal secara signifikan.

Pengaruh secara parsial norma subyektif terhadap keputusan membeli produk yang aman sebesar 0,163. Hasil tersebut signifikan karena taraf signifikansi perhitungan 3,9\% sedangkan taraf signifikansi penelitian sebesar $5 \%$, yang berarti terdapat pengaruh yang signifikan variabel norma subyektif terhadap keputusan membeli produk makanan dan minuman yang aman dan halal.

Sedangkan pengaruh secara parsial persepsi kontrol perilaku terhadap keputusan membeli makanan dan minuman yang aman sebesar 0,237 . Taraf signifikansi perhitungan $1 \%$ sedangkan taraf signifikansi penelitian sebesar 5\%, berarti terdapat pengaruh yang signifikan variabel persepsi kontrol perilaku terhadap keputusan membeli produk makanan dan minuman yang aman dan halal.

Pengaruh secara parsial niat terhadap variabel keputusan membeli produk makanan dan minuman yang aman sebesar 0,201. Taraf signifikansi perhitungan $2,3 \%$ sedangkan taraf signifikansi penelitian sebesar 5\%, yang berarti terdapat pengaruh yang signifikan niat terhadap keputusan membeli produk makanan dan minuman yang aman dan halal.

Sedangkan diperoleh angka korelasi antara variabel sikap dengan norma subyektif sebesar 0,128, menunjukkan hubungan antara variabel sikap dengan norma subyektif sangat lemah. Angka signifikansinya hasil perhitungan sebesar $0,082>0,05$, maka korelasi kedua variabel tersebut tidak signifikan. Angka korelasi antara sikap dan persepsi kontrol perilaku sebesar 0,449, menunjukkan hubungan positip dan cukup kuat. Angka signifikansi hasil perhitungan sebesar $0,00<0,05$, maka korelasi kedua variabel tersebut signifikan. Korelasi antara norma subyektif dan persepsi kontrol perilaku sebesar 0,346 cukup kuat. Angka signifikansi hasil perhitungan $0,000<0,05$ menunjukkan korelasi kedua variabel signifikan.

Pengaruh secara gabungan dari variabel sikap, norma subyektif, dan persepsi kontrol perilaku terhadap niat membeli makanan dan minuman yang halal sebesar 0,383. Angka tersebut mempunyai arti pengaruh sikap, norma subyektif, dan persepsi kontrol perilaku terhadap niat membeli makanan dan minuman yang halal sebesar secara gabungan adalah 38,3\%, sedangkan sisanya sebesar $61,7 \%$ dipengaruhi oleh variabel-variabel lain di luar model.

Pengaruh secara parsial sikap terhadap niat adalah sebesar 0,403. Hasil perhitungan menunjukkan taraf siginfikansi $0 \%<$ taraf signifikansi penelitian $5 \%$, maka pengaruh sikap terhadap niat membeli makanan dan minuman yang halal signifikan. 
Pengaruh secara parsial norma subyektif terhadap niat membeli makanan dan minuman yang halal sebesar 0,213. Hasil tersebut tidak signifikan karena taraf signifikansi perhitungan $0,7 \%$ sedangkan taraf signifikansi tabel sebesar 5\%, yang berarti pengaruh norma subyektif terhadap niat membeli produk makanan dan minuman yang halal signifikan. Sedangkan pengaruh secara parsial persepsi kontrol perilaku terhadap niat membeli makanan dan minuman yang halal sebesar 0,213. Hasil tersebut signifikan karena taraf signifikansi perhitungan $1,5 \%$ sedangkan taraf signifikansi tabel sebesar 5\%. Hasil yang diperoleh angka korelasi antara variabel sikap dengan norma subyektif sebesar 0,128, menunjukkan hubungan antara variabel sikap dengan norma subyektif sangat lemah. Angka signifikansinya hasil perhitungan sebesar 0,082>0,05, maka korelasi kedua variabel tersebut tidak signifikan. Angka korelasi antara sikap dan persepsi kontrol perilaku sebesar 0,449, menunjukkan hubungan positip dan cukup kuat. Angka signifikansi hasil perhitungan sebesar $0,00<0,05$, maka korelasi kedua variabel tersebut signifikan. Korelasi antara norma subyektif dan persepsi kontrol perilaku sebesar 0,346 cukup kuat. Angka signifikansi hasil perhitungan 0,000 < 0,05 menunjukkan korelasi kedua variabel signifikan. Korelasi antara sikap dengan niat sebesar 0,526 menunjukkan korelasi yang kuat. Angka signifikansi hasil perhitungan 0,000 $<0,05$ menunjukkan korelasi kedua variabel signifikan. Korelasi antara norma subyektif dan niat sebesar 0,338 cukup kuat. Angka signifikansi hasil perhitungan $0,000<0,05$ menunjukkan korelasi kedua variabel signifikan. Korelasi antara persepsi kontrol perilaku dengan niat sebesar 0,467 menunjukkan hubungan yang cukup kuat. Angka signifikansi hasil perhitungan $0,000<0,05$ menunjukkan korelasi kedua variabel signifikan.

Pengaruh secara gabungan dari variabel sikap, norma subyektif, dan persepsi kontrol perilaku terhadap niat membeli makanan dan minuman yang halal sebesar 0,494. Angka tersebut mempunyai arti pengaruh sikap, norma subyektif, dan persepsi kontrol perilaku terhadap niat membeli makanan dan minuman yang halal sebesar secara gabungan adalah 49,4 \%, sedangkan sisanya sebesar 50,6 \% dipengaruhi oleh variabel-variabel lain di luar model.

Besarnya pengaruh secara parsial dari sikap, norma subyektif, dan persepsi kontrol perilaku, niat terhadap keputusan membeli makanan dan minuman yang halal digunakan angka beta atau standardized coeffecient dan pengujian dilakukan dengan uj-t.

Pengaruh secara parsial sikap terhadap keputusan membeli produk makanan dan minuman yang halal adalah sebesar 0,104. Hasil perhitungan menunjukkan taraf siginfikansi $20,7 \%<$ taraf signifikansi penelitian 5\%, maka pengaruh sikap terhadap keputusan membeli makanan dan minuman yang halal tidak signifikan.

Pengaruh secara parsial norma subyektif terhadap keputusan membeli makanan dan minuman yang halal sebesar 0,088 . Hasil tersebut tidak signifikan karena taraf signifikansi perhitungan 23 $\%$ sedangkan taraf signifikansi penelitian sebesar 5\%, yang berarti tidak terdapat pengaruh yang signifikan variabel norma subyektif terhadap keputusan membeli produk makanan dan minuman yang halal.

Sedangkan pengaruh secara parsial persepsi kontrol perilaku terhadap keputusan membeli makanan dan minuman yang halal sebesar negatip 0,037. Taraf signifikansi perhitungan $64,7 \%$ sedangkan taraf signifikansi penelitian sebesar 5\%, berarti tidak terdapat pengaruh yang signifikan variabel persepsi kontrol perilaku terhadap keputusan membeli produk makanan dan minuman yang halal. 
Pengaruh secara parsial niat terhadap variabel keputusan membeli produk makanan dan minuman yang halal sebesar 0,627. Taraf signifikansi perhitungan $0 \%$ sedangkan taraf signifikansi penelitian sebesar $5 \%$, yang berarti terdapat pengaruh yang signifikan niat terhadap keputusan membeli produk makanan dan minuman yang halal.

\section{KESIMPULAN DAN SARAN}

Berdasarkan hasil penelitian dan pembahasan yang telah dilakukan, maka dapat kesimpulan sebagai berikut :

Produk makanan dan minuman yang aman, Pengaruh variabel persepsi kontrol perilaku terhadap keputusan membeli produk makanan dan minuman yang aman sebesar 23,7 \%; Pengaruh variabel niat terhadap keputusan membeli produk makanan dan minuman yang aman sebesar 20,1\%.;Pengaruh variabel sikap, norma subyektif, persepsi kontrol perilaku, dan niat terhadap keputusan membeli produk makanan dan minuman yang aman secara gabungan sebesar $34,9 \%$; Pengaruh variabel-variabel lain di luar model terhadap keputusan membeli produk makanan dan minuman yang aman sebesar $65,1 \%$; Pengaruh variabel sikap terhadap niat membeli produk makanan dan minuman yang aman sebesar 24,5\%.;Pengaruh variabel norma subyektif terhadap niat membeli produk makanan dan minuman yang aman sebesar 13,6\%.; Pengaruh variabel persepsi kontrol perilaku terhadap niat membeli produk makanan dan minuman yang aman sebesar 29,4 \%.; Pengaruh variabel sikap, norma subyektif, dan persepsi kontrol perilaku secara gabungan terhadap niat membeli produk makanan dan minuman yang aman sebesar 23,4 \%; Pengaruh variabel lain di luar model terhadap niat membeli produk makanan dan minuman yang aman sebesar $76,6 \%$.

Produk makanan dan minuman yang halal; Pengaruh variabel persepsi kontrol perilaku terhadap keputusan membeli produk makanan dan minuman yang halal sebesar 23,7 $\%$.;Pengaruh variabel niat terhadap keputusan membeli produk makanan dan minuman yang halal sebesar 20,1\%.; Pengaruh variabel sikap, norma subyektif, persepsi kontrol perilaku, niat terhadap keputusan membeli produk makanan dan minuman yang halal secara gabungan sebesar 49,4 \%.; Pengaruh variabel-variabel lain di luar model terhadap keputusan membeli produk makanan dan minuman yang halal sebesar 50,6\%.; Pengaruh variabel sikap terhadap niat membeli produk makanan dan minuman yang halal sebesar 40,3\%.; Pengaruh variabel norma subyektif terhadap niat membeli produk makanan dan minuman yang halal sebesar $21,3 \%$.

\section{UCAPAN TERIMA KASIH ( ACKNOWLEDGEMENT )}

Pada kesempatan ini kami ingin megucapkan banyak terima kasih kepada semua pihak yang telah mendukung keberhasilan penelitian ini, terutama kepada Direktur DPPM beserta Staf Universitas Tarumanagara yang telah membiayai penelitian ini, juga terima kasih kepada Dekan FE Untar serta kepada Bapak/Ibu Dosen/Karyawan dan Mahasiswa atas kesediaannya menjadi responden pada penelitian ini.

\section{REFERENSI}

Anna P. Roswiem, (2010), Krisis Kehalalan Bahan Produk Makanan, LP POM MUI Azwar, Saifuddin. (2007), Sikap Manusia, Teori dan Pengukurannya; Penerbit: Pustaka Pelajar, Jakarta.

Aritonang, Lerbin R. (1998), Penelitian Pemasaran. Jakarta: UPT Untar penerbitan

Assadi Djamchid (2003). Do Religions Influence Customer Behavior? Confronting Religious Rules and Marketing Concepts.Cahiers du CEREN Volume: 5: 2-13 
Ajzen, I. (1991). The theory of planned behavior. Organizational Behavior and Human Decision Processes, 50:179-211.

Bonne, Karijn et Wim Verbeke (2006). Muslim consumer's motivations towards meat consumption in Belgium: qualitative exploratory insights from means-end chain analysis, http://aof.revues.org/document90.html

Basu Swastha dan T. Hani Handoko, 2005,Manajemen. Pemasaran, Analisa Perilaku Konsumen. BPFE, Yogyakarta.

Cooper, Donald R. and Schindler, Pamela, S.( 2006), Metode Riset Bisnis, Volume 2, Jakarta: Grafindo.

Essoo, Nittin and Dibb, Sally (2004). Religious influences on shopping behaviour: an exploratory study. Journal of Marketing Management, 20 (7-8). P.: 683-712. ISSN 0267-257X

Endang, Soesilowati (2009). Peluang Usaha Produk Halal di Pasar Global: Perilaku Konsumen Muslim dalam Konsumsi Makanan Halal. Jakarta: P2E-LIPI

Hawkins et.al in Suryani, Tatik (2008), Perilaku Konsumen, Edisi Pertama, Yogjakarta: Ghalia Ilmu.

Harold H. Kasrian dan Thomas S. Robertson (1981), Perspective in Consumer Behavior, GlenView, IL, Scoot Foresman.

Kotler, Philip (1995), Manajemen Pemasaran: Analisis, perencanaan, Implementasi, dan Pengendalian.Jakarta : Salemba Empat (2003), Manajemen Pemasaran, Ed. 11, Jakarta: Index Kelompok Gramedia.

\section{Jersey;Prentice Hall.}

(2008), Marketing Management, 14 Ed, Pearson Internasional, New

Mada, Yudhi Prasetya. (2005). Analisis Pengaruh Sikap terhadap Perilaku, Norma Subyektif dan Kontrol Kepemilikan yang Dirasakan terhadap Niat dan Perilaku Konsumen. Infestasi, 1 (1), h: $79-88$

Malhotra, Naresh K. (2005); "Marketing Research: an Applied Orientation, Fourth Edition, New Jersey: Printice-Hall, Inc.

Muhammad, M, and Omar, A. (2008). An Analysis of the Muslim Consumer' attitude towards 'Halal' Food Products in Kelantan. Thrusting Islam Knowledge and Professionalism in ECER Development. ECER Regional Conference. 15-17 Desember 2008. Malaysia

Nur, Hidayah dan Tony, M. Nawawi (2011): Faktor-faktor yang mempengaruhi Pemilihan Produk Kosmetik pada Karyawati Muslimah di Untar, Jakarta. LPPI-Untar, Jakarta. 
Ujang, Sumarwan, ( 2003) , Perilaku Konsumen, Teori dan Penerapannya dalam Pemasaran; Ghalia Indonesia, Jakarta.

Pusat Pengkajian dan Pengembangan Ekonomi Islam (P3EI). (2008). Ekonomi Islam. PT. Raja Grafindo Persada: Jakarta

Setiadi, Nugroho (2003), Perilaku Konsumen dan Aplikasinya untuk Strategi dan Penelitian Pemasaran; Kencana, Jakarta.

Sanusi, Anwar (2011), Metode Penelitian Bisnis, Salemba Empat, Jakarta.

Sarwono, Jonathan (2007), Analisis Jalur untuk Riset Bisnis dengan SPSS, Yogjakarta: Andi Offset.

Sensus Penduduk tahun 2010, BPPS.Jakarta.

Schiffman dan Kanuk (2000), Perilaku konsumen. Jakarta: PT. Indeks

Shafie S, Othman N Md, (2006). Halal Certification: an international marketing issues and challenges. http://www.ctwcongress.de/ifsam/download/track_13/pap00226.pdf. diakses pada 14 November 2014.

Yusuf ,Qardhawi (2000). Halal dan Haram dalam Islam, Surabaya : P.T. Bina Ilmu. www.halalmui.org.

Simamora, Bilson. (2002). Panduan Riset Perilaku Konsumen. Gramedia: Jakarta Sofyan Assauri, (2004), Manajemen Pemasaran ;Dasar, Konsep dan Strategi. Grafindo Persada. Jakarta. 